\title{
A fé cristã como possibilidade de uma verdadeira existência humana, segundo Joseph Ratzinger
}

\author{
Orientador: Mario de França Miranda \\ Mestrando: Gilcemar Hohemberger \\ Área de Concentração: Teologia Sistemático-Pastoral \\ Linha de Pesquisa: Fé e Cultura
}

A fé cristã como possibilidade de uma verdadeira existência humana, busca fazer uma leitura do pensamento teológico de Joseph Ratzinger, sistematizando a temática da fé cristã e demonstrando a força e vitalidade que a tornam possibilidade de uma verdadeira existência humana nos dias de hoje. O cenário que faz fundo a este estudo é a questão da verdade e a crise da fé no contexto moderno. Diante da atual conjuntura cultural e teológica da fé cristã, o cristianismo encontra-se perante num verdadeiro dilema: a compreensão moderna de realidade, na qual o alcance cognoscitivo se limita ao sensível, ao que é fenomênico, onde a única realidade existente é a matéria, estabelecendo assim um reinado do factível e o predomínio de uma filosofia: o relativismo. A fé cristã, no entanto, vai além daquilo que a pura razão é capaz de reconhecer, vai ao encontro de Cristo, do logos, do sentido, da própria verdade. $\mathrm{O}$ ser humano não pode ser sustentado somente pelo que é visível e tangível, pelo mensurável, por isso a fé o impele a uma abertura decisiva para o Logos. Portanto, a fé cristã não é um sistema, uma ideia, uma entrega cega ao irracional, mas pertence ao âmbito da verdade, pois é a opção para a prioridade da razão e do racional. Crer é razoável. Assim, é possível compreender a função humanizadora da fé cristã e sua estrutura pessoal: a essência da fé cristã consiste em aceitar e viver a existência como relacionalidade, cuja fórmula central é "Creio em ti" e não "Creio em algo". Nessa relação com Deus Pessoa se instaura a primazia do amor: ser cristão é humanizar-se pelo amor. Um Deus-Amor que atua de modo transtemporal e translocalmente, promovendo um encontro da fé com as culturas, não para privá-las de algo, antes para constituir um estímulo à busca da plenitude da verdade. Esta síntese do pensamento de Ratzinger sobre a fé cristã quer afirmar que, somente em Deus, o ser humano alcança o sentido da vida, uma real e verdadeira existência humana.

Palavras-chave: Fé cristã, Verdade, Razão, Deus. 